\title{
The correlation between metacognitive skills and scientific attitudes towards the retention of male and female students in South Sulawesi, Indonesia
}

\author{
Romi Adiansyah', Aloysius Duran Corebima ${ }^{2}$, Siti Zubaidah ${ }^{3}$, Fatchur Rohman ${ }^{4}$ \\ ${ }^{1,3,4}$ Department of Biology, Faculty of Mathematics and Natural Sciences, Universitas Negeri Malang, Malang, Indonesia \\ ${ }^{1}$ Department of Biology Education, Faculty of Teacher Training and Education Science, Muhammadiyah Bone \\ University, South Sulawesi, Indonesia \\ ${ }^{2}$ Faculty of Science and Technology, PGRI University of Kanjuruhan Malang, Indonesia
}

\begin{tabular}{|c|c|}
\hline Article Info & ABSTRACT \\
\hline Article history: & This was quantitative correlational research, which investigated the \\
\hline Received Jan 19, 2021 & correlation between metacognitive skills and scientific attitudes towards the \\
\hline Revised Aug 12, 2021 & research sample was biology education students in the second semester, with \\
\hline Accepted Sep 9, 2021 & $\begin{array}{l}104 \text { students consisting of } 47 \text { males and } 57 \text { females. The instruments } \\
\text { employed in this study were those for assessing metacognitive skills, }\end{array}$ \\
\hline Keywords: & $\begin{array}{l}\text { scientific attitudes, and retention. Metacognitive skills and retention were } \\
\text { measured using essay tests, while scientific attitudes were measured using }\end{array}$ \\
\hline Female students & observation sheets. The results indicated that the value of the simultaneous \\
\hline Male students & $\begin{array}{l}\text { contribution of metacognitive skills and scientific attitudes towards to the } \\
\text { retention of female students was higher than that of male students. The }\end{array}$ \\
\hline Metacognitive skills & effective contributions of metacognitive skills and scientific attitude towards \\
\hline Retention & male students' retention were $3.33 \%$ and $24.67 \%$. Metacognitive skills and \\
\hline Scientific attitude & $\begin{array}{l}\text { scientific attitudes both contribute } 14.5 \% \text { and } 17.2 \% \text {, respectively, to female } \\
\text { students' retention. }\end{array}$ \\
\hline
\end{tabular}

This is an open access article under the CC BY-SA license.

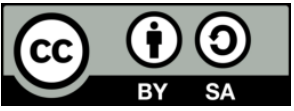

\section{Corresponding Author:}

Aloysius Duran Corebima

Faculty of Science and Technology

PGRI University of Kanjuruhan Malang

Malang, Jawa Timur 65148, Indonesia

Email: durancorebima@gmail.com

\section{INTRODUCTION}

Retention is an essential indicator in the learning process [1], [2]. Retention is the capacity to recall a piece of learning content for a specified period of time. It is also a fundamental component of learning [3]. Memory has a vital role in the learning process in memorization, but also more on the dimension of critical thinking, learning, associating, remembering, and using all the knowledge and abilities obtained [4], [5]. Additionally, a study defined retention as a person's capacity to store information acquired in memory [6].

The learning process is not possible without retention, and retention will not be possible, without the learning process [7], [8]. Therefore, every person needs to have retention in any case. For instance, if a student is presented with an issue to solve, the student should be able to hone his critical thinking and retention skills [9], [10]. However, retention can be influenced by various factors, one of which is metacognitive skills.

Recent research in science learning emphasizes the importance of applying metacognitive skills [11]. Metacognitive skills become the basis of independent learning in the 21st century [12], [13]. 
Metacognitive skills are higher-order thinking skills about thinking that involve cognitive processes [14], [15]. Every student must have metacognitive skills in planning, monitoring, and evaluating in the problemsolving process [16], [17]. Also, students who have good metacognitive skills can control their minds, be able to quickly recognize learning material that they do not know and be able to decide, continue or stop the learning process [18], [19].

In addition to metacognitive skills, scientific attitude is also a factor contributing to retention. Scientific attitude is defined as a tendency, readiness, honesty, curiosity, willingness to give responses/actions/behavior in science that has been proven true [20], [21]. Also, scientific attitude is one-way used by researchers to be considered in making decisions or taking actions [22]. This scientific attitude becomes the basic goal of science learning to be developed and must be achieved by all students because scientific attitude is one of the cognitive components [23], [24].

In addition to metacognitive skills, scientific attitudes, and retention; gender also influences the learning processes [25]. Gender, in a narrow sense, is the gender differences, namely male and female [26]. Gender is an essential factor in the learning process and affects various things, for example, in problem solving of science learning, female students are superior to male students [27]. This condition is caused by the fact that male students' metacognition is not very good to be used in the learning process, compared to that of female students [28]. In general, gender differences become disparities in science, from birth until higher education levels [29]. The efforts to achieve gender equality in education have still been continually made [30]. Gurel found that female students had better knowledge than male students. Thus, gender is believed to have a correlation with students' thinking development, including metacognitive skills [31].

Many kinds of correlational research using metacognitive skills as the predictor variable have been conducted in the last decade. The studies found a substantial relationship between students' metacognitive skills and retention [1], [32]-[34]. Additionally, it was discovered that students' metacognitive skills correlated positively with the improvement of their learning outcomes [35]. Research results related to metacognitive skills and scientific attitudes in Indonesia's learning process are still relatively low. The research conducted in senior high schools reported that students' metacognitive skills were categorized as low [36]. Other research results also show that relatively university-level metacognitive skills are still low [37]. The research results of Amnah supporting the low value of metacognitive skills possessed by these university students, also reported that the data of metacognitive skills were in the category of "very risky", and the scientific attitude was in the "low" category [38]. Therefore, metacognitive skills and scientific attitudes need to be empowered and enhanced.

Related to research on gender, it was reported that female students were superior to male verbal skills [39]. There is a difference between male and female students in learning; females are more mature in language, more vital memorization, more confident, and able to handle the situation more successfully [40], [41]. It can also be seen that the female students tend to have better questioning skills, sensitive to social work, better cooperation skills, more precise, and more credible than the male students [42].

The female students have better skills in explaining problem solving procedures and strategies clearly and organized [43]. Female students develop better metacognitive skills than the male students [44]. Garzon, Bistos, and Lizarazo research discovered that there was no statistically significant difference between female and male metacognitive skills [45]. This outcome is consistent with the previous findings showing there is no statistically significant difference between female and male scientific attitudes [46]. Nevertheless, a study reported that gender had a significant effect on students' learning styles and scientific attitudes [47].

There has been a dearth of research into the various correlations between metacognitive skills and scientific attitudes towards male and female students' retention. Therefore, it is necessary to conduct this research because the multiple correlation between the predictor and criterion variables is stronger and more real than a single correlation. Numerous studies continue to focus on straightforward relationships between metacognitive skills and scientific attitudes, metacognitive skills and retention, and metacognitive skills and learning outcomes. Additionally, they examine the relationship between metacognitive abilities and critical thinking, as well as the relationship between metacognitive abilities and other characteristics.

Therefore, this research was conducted to investigate the correlation between metacognitive skills and scientific attitudes towards the retention of male and female students, especially in South Sulawesi, Indonesia. These research results are expected to give students or teachers/lecturers the right learning strategy or learning model, which improves students' learning results. Besides, it can also give useful information for educational curriculum development. 


\section{RESEARCH METHOD}

\subsection{Research model}

This research is a correlational study. This study aims to determine the relationship between metacognitive skills and scientific attitudes towards student retention. Metacognitive skills and scientific attitudes in this study act as predictors and student retention acts as criteria.

\subsection{Participants}

The study enrolled 104 biology education students in the second semester of the 2017/2018 academic year, 47 of whom were male and 57 of whom were female. These samples were distributed over Universitas Muhammadiyah Makassar and STKIP Pembangunan Indonesia, Makassar. This study was conducted from April to August 2018.

\subsection{Research instrument}

The instruments in this research were used to measure students' metacognitive skills, scientific attitudes, and retention. The students' metacognitive skills and concept gaining were measured using an integrated essay test [48], with open-ended assessment pattern in Environmental Knowledge Course. The essay test consisted of 14 test items which had been declared valid and reliable. The instrument's validity test was done by performing confirmatory factor analysis. It obtained a factor weighting value of $>0.3$ and a T-value of \pm 1.96 (all metacognitive skills instrument items were declared valid). The Alpha Cronbach's coefficient related to the metacognitive skills instruments shows a value of 0.959 (consistent or reliable).

The data of the students' scientific attitudes were obtained using observation sheets. The scientific attitude questionnaire consisted of 36 valid and reliable statements. The scientific attitude indicators used referred to the nine indicators, namely: curiosity, rationality, willingness to suspend judgment, positive attitude towards failure, intellectual honesty, objectivity, open- mindedness, humility, cooperation [22]. Every five students will be observed by one observer so that the results obtained are more accurate. The results of the expert validation for the scientific attitude questionnaire and for the scientific attitude observation sheets obtained an average score of 4.00 (vary valid category) and 3.90 (very valid category) respectively. The data of the students' scientific attitude were obtained by looking at the weight of the instrument factor $>0.3$ and a $T$ - value of \pm 1.96 , which was declared valid. The Cronbach's Alpha coefficient shows a value of 0.977 , which was declared consistent or reliable.

\subsection{Data collection}

The data were collected from the pretest, posttest, and retention test (two weeks after the posttest). The classroom learning activities were conducted for 16 meetings, in which two meetings were used for tests and 14 meetings were for learning activities. The rubric for metacognitive skills in this research referred to the developed metacognitive skill score rubric [48]. The rubric included eight measures (0-7), which were used to evaluate students' responses to each test item. According to Green [49], the levels of metacognitive skills are as: "super (85-100), ok (68-84), development (51-67), cannot really (34-50), risk (17-33), and not yet (0-16)." The rubric scores were calculated using the metacognitive skill formula [48].

$$
\frac{y 1+2 x}{3}=\mathrm{y} 2
$$

Description:

y1 = concept gaining score

y2 $=$ the combination between concept gaining score and metacognitive skills score

$\mathrm{x}=$ metacognitive skills score

The data of the students' scientific attitudes were obtained using observation sheets that had been validated by experts. The categories of the results of observations were determined by giving scores and criteria (very low, low, medium, good, and very good), while the scientific attitude questionnaire used the Likert scale.

\subsection{Data analysis}

The Kolmogorov-Smirnov test was used to examine whether or not the research data were regularly distributed. Following that, the hypothesis was investigated using multiple regression analysis with a 5\% significance level to ascertain the correlation and contribution of metacognitive skills and scientific attitudes on student retention. 


\section{RESULTS AND DISCUSSION}

\subsection{The correlation between metacognitive skills and scientific attitudes towards the retention of male} students

The correlation between metacognitive skills and scientific attitudes regarding retention of male students is summarized in Table 1 to Table 3. The Anova test results in Table 1 indicate that the $\mathrm{F}$ value is 8.560 with a significance level of 0.001 . This demonstrates a significant association between metacognitive skills and scientific attitudes toward male students' retention. The results of the analysis in Table 2 show that the regression equation was $\mathrm{Y}=16.141+0.063 \mathrm{X}_{1}+0.569 \mathrm{X}_{2}$. The results of the analysis in Table 3 show that the correlation coefficient $(\mathrm{R})$ is 0.529 having a contribution value $\left(\mathrm{R}^{2}\right)$ of 0.280 . This means that the value of the simultaneous contribution of metacognitive skills and scientific attitudes towards retention is $28 \%$.

Table 1. Summary of Anova on the correlation between metacognitive skills and scientific attitudes towards the retention of male students

\begin{tabular}{clccccc}
\hline Model & & Sum of Squares & df & Mean Square & F & Sig. \\
\hline \multirow{2}{*}{1} & Regression & 512.286 & 2 & 256.143 & 8.560 & $.001^{\mathrm{b}}$ \\
& Residual & 1316.691 & 44 & 29.925 & & \\
& Total & 1828.977 & 46 & & & \\
\hline
\end{tabular}

Table 2. Regression coefficient of metacognitive skills and scientific attitudes towards the retention of male students

\begin{tabular}{clccccc}
\hline \multirow{2}{*}{ Model } & & Unstandardized coefficients & \multirow{2}{*}{ Std. Error } & $\begin{array}{c}\text { Coefficients standardized } \\
\text { Beta }\end{array}$ & \multirow{2}{*}{ Sig. } \\
\cline { 3 - 7 } \multirow{2}{*}{1} & B & 16.141 & 9.614 & & 1.679 & .100 \\
& Meta & .063 & .134 & .108 & .470 & .641 \\
& Scientific attitude & .569 & .213 & .616 & 2.668 & .011 \\
\hline
\end{tabular}

Table 3. Summary of the results of multiple regression related to the correlation between metacognitive skills and scientific attitudes towards retention of male students

\begin{tabular}{ccccc}
\hline Model & R & R Square & Adjusted R Square & Std. Error of the estimate \\
\hline 1 & $.529^{\mathrm{a}}$ & .280 & .247 & 5.47036 \\
\hline
\end{tabular}

Table 4 summarizes the findings of an examination of the influence of metacognitive skills and scientific attitudes to male students' retention. The results of the analysis in Table 4 show that the effective contributions of metacognitive skills and scientific attitudes towards retention are $3.33 \%$ and $24.67 \%$, respectively.

Table 4. Contributions of metacognitive skills and scientific attitudes towards the retention of male students

\begin{tabular}{ccc}
\hline Variable & $\mathrm{RC}(\%)$ & $\mathrm{EC}(\%)$ \\
\hline X1 (metacognitive skills) & 11.89 & 3.33 \\
X2 (scientific attitude) & 88.11 & 24.67 \\
Total & 100 & 28.0 \\
\hline
\end{tabular}

\subsection{The correlation between metacognitive skills and scientific attitudes towards the retention of female students}

The correlation between metacognitive skills and scientific attitudes regarding retention of female students is summarized in Table 5 to Table 7. The results of the Anova test in Table 5 show that the $\mathrm{F}$ value $=12.519$ with a significance value of 0.000 . The analysis results show a very significant correlation between metacognitive skills and scientific attitudes towards the retention of female students. The analytical results in Table 6 indicate that the regression equation found is $Y=17.860+0.191 X_{1}+0.319 X_{2}$. The results of the analysis in Table 7 show that the correlation coefficient $(\mathrm{R})$ is 0.563 having a contribution value $\left(\mathrm{R}^{2}\right)$ of 0.317 . This suggests that the combined effect of metacognitive skills and scientific attitudes on retention is $31.7 \%$. 
Table 5. Summary of Anova on the correlation between metacognitive skills and scientific attitudes towards the retention of female students

\begin{tabular}{clccccc}
\hline Model & & Sum of Squares & df & Mean Square & F & Sig. \\
\hline \multirow{2}{*}{1} & Regression & 535.881 & 2 & 267.941 & 12.519 & $.000^{\mathrm{b}}$ \\
& Residual & 1155.779 & 54 & 21.403 & & \\
& Total & 1691.660 & 56 & & & \\
\hline
\end{tabular}

Table 6. Regression coefficient of metacognitive skills and scientific attitudes towards the retention of female students

\begin{tabular}{|c|c|c|c|c|c|c|}
\hline Model & & $\begin{array}{c}\text { Unstandardized Coefficients } \\
\text { B }\end{array}$ & Std. Error & $\begin{array}{c}\text { Coefficients Standardized } \\
\text { Beta }\end{array}$ & $\mathrm{t}$ & Sig. \\
\hline \multirow[t]{3}{*}{1} & (Constant) & 17.860 & 8.135 & & 2.196 & .032 \\
\hline & Meta & .191 & .102 & .286 & 1.883 & .065 \\
\hline & Scientific attitude & .319 & .147 & .330 & 2.176 & .034 \\
\hline
\end{tabular}

Table 7. Summary of the results of multiple regression related to the correlation between metacognitive skills and scientific attitudes towards retention of female students

\begin{tabular}{ccccc}
\hline Model & R & R Square & Adjusted R Square & Std. Error of the estimate \\
\hline 1 & $.563^{\text {a }}$ & .317 & .291 & 4.62637 \\
\hline
\end{tabular}

The results of the analysis of the contribution of metacognitive skills and scientific attitudes towards the retention of female students can be seen in Table 8. The results of the investigation in Table 8 indicate that metacognitive skills and scientific attitudes make beneficial contributions to retention of $14.5 \%$ and $17.2 \%$, respectively.

Table 8. Contributions of metacognitive skills and scientific attitudes towards the retention of female students

\begin{tabular}{ccc}
\hline Variable & $\mathrm{RC}(\%)$ & $\mathrm{EC}(\%)$ \\
\hline X1 (metacognitive skills) & 45.75 & 14.5 \\
X2 (scientific attitude) & 54.25 & 17.2 \\
Total & 100 & 31.7 \\
\hline
\end{tabular}

According to the results of the multiple linear regression analysis, there is a strong correlation between metacognitive skills and scientific attitudes toward retention in both male and female students. The regression equation is $\mathrm{Y}=16.141+0.063 \mathrm{X}_{1}+0.569 \mathrm{X}_{2}$ with the simultaneous contribution between metacognitive skills and scientific attitudes towards male students' retention as much as $28 \%$. The regression equation is $\mathrm{Y}=17.860+0.191 \mathrm{X}_{1}+0.319 \mathrm{X}_{2}$ with simultaneous contribution between metacognitive skills and scientific attitudes towards female students' retention as much as $31.7 \%$. Furthermore, this research shows that the contribution of metacognitive skills and scientific attitudes towards retention in female students is higher than that in male students.

The findings of this study corroborate previous research indicating that female pupils possess superior verbal abilities over male students [41]. This is consistent with the theory stating that males' and females' brain functions are different [50]. The differentiating factor between female students and male students is in language and skills [51]. Female pupils listen and speak with their left brains, whereas communication tasks are mostly conducted with their left brains. Thus, the left brain is critical for female language abilities [52]. Female students are more sensitive to social work and group work, and they have better questioning skills and are more credible and stronger in language and writing than male students [53]. The male students are superior in reasoning abilities, visual-spatial, mathematics and mechanics, while the female students are superior in accuracy, precision, and thinking [54].

Other research also shows that women are more concerned with concrete, practical, emotional, and personal things, while men are concerned with intellectual, abstract, and objective things. Therefore, women are superior, more accurate, and more detailed in doing stuff than men [55], [56]. Moreover, female students also use more learning strategies in the learning process to have high intelligence [57], [58]. The male students tend to show positive attitudes towards science and to have the desire to be scientist as the futurecareer path [59].

Internal factors and external factors can influence retention. The internal factors include health, talents, interests, motivation, intelligence, and memorization skills. In comparison, the external factors 
include family, school, environment, and community factors. Metacognitive skills and scientific attitudes are internal factors that are self-developed in students. Thus, female students have more optimal metacognitive skills than male students [60]. The students who have good metacognitive skills will have more confidence in actualizing themselves in scientific activities and scientific processes. As a result, the learning objectives can be more effectively achieved [61], [62]. The effectiveness of achieving learning objectives plays a role in increasing retention.

Scientific attitude refers to the capacity to act consistently, rationally, and objectively in a particular way in response to challenges, which is manifested in one's behavior [63]. Scientific attitude includes curiosity, open-mindedness, discovery attitude, open attitude, honesty, critical thinking, goals, responsibilities, cooperation, and firm attitude [64]. People who have positive scientific attitudes will positively affect their learning process [65]. This fact can be seen from the results of effective contributions in this research (Table 4 and Table 8).

Previous research findings indicated a considerable disparity in attitudes toward science between female and male students [66]. The research results conducted by Mihladiz, Duran, and Dogan showed that the female students had better scientific attitudes than the male students [67]. On the other hand, some other studies found no substantial difference in female and male students' views toward science.

The effective contribution of metacognitive skills towards retention in this research is much as $17.83 \%$, and the effective contribution of scientific attitudes towards retention is as much as $41.87 \%$. This research proves that metacognitive skills and scientific attitudes simultaneously provide a significant effective contribution towards retention of both male students and female students. Therefore, students must possess good metacognitive skills and scientific attitudes to achieve satisfying learning results. This result is in line with report saying that metacognitive skills and scientific attitudes are two important factors in the learning process, and both have a strong correlation with retention [68].

Metacognitive skills also play an important role in regulating and controlling one's cognitive processes, and a critical aspect of cognitive components is the scientific attitude [69]. To be an independent learner requires not only metacognitive skills and the ability of the male and female students, but also the development of the students' scientific attitudes and retention [70]. This is in line with the research results reporting that the students who have good academic achievement will most likely have good metacognitive skills, scientific attitudes, and retention [71]. Therefore, the students are capable of showing good attitudes to organize their learning more effectively and to decide the best time for learning and for reviewing the learning materials [72].

Similar research results also reported that the metacognitive skills and the scientific attitudes of both male and female students are cognitive components which are interrelated with each other [73]. Therefore, it is important to develop students' scientific attitudes [74]. The development of scientific attitudes is not only for research purposes or science learning purposes but also for human life quality for both males and females [75]. The increase of scientific attitudes is also related to gender, academic achievement, parents' profession, education, economics, and learning styles that become the characteristics of the students in interacting and reacting to the learning environment during the learning process [74], [76]. Besides, scientific attitudes also significantly affect students' minds or memories and actions [77].

To increase the contribution of scientific attitudes towards retention can be done by implementing appropriate learning strategies [78]. This is important because retention is one of the key components of learning success [7]. Students who have high metacognitive skills and scientific attitudes will quickly memorize the learning material to get high test results. This opinion is in line with the research results, stating that retention does not only involve the process of remembering or memorizing but also involves one's cognitive ability in evaluating his or her success [79], [80].

Related to the results of this research proving that metacognitive skills and scientific attitudes have a significant correlation with retention, metacognitive skills and scientific attitudes are interconnected. Metacognitive skills involve a cognitive process. Similarly, scientific attitudes require cognitive processes to simultaneously empower retention, thus obtaining a very effective contribution to the improvement of retention of both male students and female students in learning. Furthermore, other factors that can influence and increase students' retention can be further investigated in future research.

The results of this research are expected to give contributions to educators, both teachers and lecturers, in various disciplines to empower students' metacognitive skills and scientific attitudes in the learning activities. The learning scenario which involves those components is expected to enrich the quality of science learning. Teachers and lecturers should be able to guide their students to develop their scientific attitudes through investigation activities. Furthermore, teachers and lecturers should train their students to do planning, monitoring, evaluating, and solving problems. This effort is expected to provide a more meaningful learning which can effectively increase students' retention. It is expected that both male and female students can contribute to the advancement of science and the increase of competence to face the global challenges. 


\section{CONCLUSION}

The study found that there is a substantial relationship between metacognitive skills and scientific attitudes toward retention among male and female students in South Sulawesi, Indonesia. The combined effect of metacognitive skills and scientific attitudes on female students' retention is $31.7 \%$ more than the combined effect on male stub dents' retention, which is $28 \%$. The effective contributions of metacognitive skills and scientific attitudes towards male students' retention are $3.33 \%$ and $24.67 \%$, respectively. Furthermore, the effective contributions of metacognitive skills and scientific attitudes towards female students' retention are $14.5 \%$ and $17.2 \%$, respectively. This study illustrates the need for maximum empowerment of metacognitive skills, scientific attitudes that will be useful to raise the student retention, especially for male students during the biology learning process. In addition, this study can be used as a comparison for other studies in examining the relationship between metacognitive skills, scientific attitudes and retention.

\section{ACKNOWLEDGEMENTS}

The authors express their gratitude to The Indonesia Endowment Fund for Education PRJ6586/LPDP.3/2016 and the Ministry of Research, Technology, and Higher Education of the Republic of Indonesia as the scholarship provider from the Ministry of Finance Indonesia.

\section{REFERENCES}

[1] K. Nurisya, A. D. Corebima, and F. Rohman, "The correlation between students' metacognitive skills and retention in PBL-based biology learning in senior high school," (in Indonesia), Seminar Pendidikan dan Saintek, 2016, pp. 910-914.

[2] Y. Talar and J. Gozaly, "Student retention in Indonesian private university," International Journal of Evaluation and Research in Education (IJERE), vol. 9, no. 3, pp. 486-493, 2020, doi: 10.11591/ijere.v9i3.20582.

[3] L. W. Anderson and D. R. Krathwohl, A Taxonomy for Learning, Teaching, and Assessing, a Revision of Bloom's Taxonomy of Educational Objectives. New York: Addison Wesley Longman, Inc, 2001.

[4] A. R. Haniah, Aman, and R. Setiawan, "Integration of strengthening of character education and higher order thinking skills in history learning," Journal of Education and Learning (EduLearn), vol. 14, no. 2, pp. 183-190, 2020, doi: 10.11591/edulearn.v14i2.15010.

[5] T. M. Sholihah and B. Lastariwati, "Problem based learning to increase competence of critical thinking and problem solving," Journal of Education and Learning (EduLearn), vol. 14, no. 1, pp. 148-154, 2020, doi: 10.11591/edulearn.v14i1.13772.

[6] F. Tapilow and S. Wawan, "Improving students' concept gaining and retention by interactive multimedia technology based learning (Empirical study on nerve system concepts)," (in Indonesia), Jurnal Pendidikan Teknologi Informasi Dan Komunikasi, vol. 1, no. 2, pp. 19-26, 2008.

[7] N. Ismirawati, A. D. Corebima, S. Zubaidah, and I. Syamsuri, "ERCoRe learning model potential for enhancing student retention among different academic ability," Eurasian J. Educ. Res., vol. 18, no. 77, pp. 19-34, 2018. [Online]. Available: https://dergipark.org.tr/en/pub/ejer/issue/42545/512694.

[8] A. S. Modrek, D. Kuhn, A. Conway, and T. Arvidsson, "Cognitive Regulation, Not Behavior Regulation, Predicts Learning," Learning and Instruction, vol. 60, pp. 237-244, 2018.

[9] F. Tentama and M. Z. Nur, "The correlation between self-efficacy and peer interaction towards students' employability in vocational high school," International Journal of Evaluation and Research in Education (IJERE), vol. 10, no. 2, pp. 8-15, 2021, doi: 10.11591/ijere.v10i1.20573.

[10] Tanti, A. D. Kurniawan, L. Anggraini, and R. Perdana, "A study analysis of student attitude to science lessons," Journal of Education and Learning (EduLearn), vol. 14, no. 4, pp. 566-574, 2020, doi: 10.11591/edulearn.v14i4.16097.

[11] R. F. Mustofa, A. D. Corebima, E. Suarsini, and M. Saptasari, "The Correlation between Generic Skills and Metacognitive Skills of Biology Education Students in Tasikmalaya Indonesia Through Problem-Based Learning Model," The Journal of Social Sciences Research, vol. 4, no. 5. pp. 951-956, 2019.

[12] M. R. Sari, K. I. S. Astina, H. D. Utomo, and Ridwan, "Measuring Students Scientific Learning Perception and Critical Thinking Skill Using Paper-Based Testing: School and Gender Differences," International Journal of Emerging Technologies in Learning (iJET), vol. 14, no. 19, pp. 132-149, 2019.

[13] I. Kozikoglu, "Investigating Critical Thinking in Prospective Teachers: Metacognitive skills, problem solving skills and academic self-efficacy," Journal of Social Studies Education Research, vol. 10, no. 2, pp. 111-130, 2019.

[14] Z. S. Pamungkas, N. S. Aminah, and F. Nurosyid, "Analysis of students' metacognition level in solving scientific literacy on the topic of static fluid," Journal of Education and Learning (EduLearn), vol. 13, no. 1, pp. 66-73, 2019, doi: 10.11591/edulearn.v13i1.10056.

[15] Yuberti, S. Latifah, A. Anugrah, A. Saregar, Misbah, and K. Jermsittiparsert "Approaching Problem-Solving Skills of Momentum and Impulse Phenomena Using Context and Problem-Based Learning," European Journal of Educational Research, vol. 8, no. 4, pp. 1217-1227, 2019, doi: 10.12973/eu-jer.8.4.1217. 
[16] M. I. Sukarelawan, D. Sulisworo, Jumadi, H. Kuswanto, and S. A. Rofiqah, "Heat and temperature metacognition awereness inventory: A confirmatory factor analysis," International Journal of Evaluation and Research in Education (IJERE), vol. 10, no. 2, pp. 389-395, 2021, doi: 10.11591/ijere.v10i2.20917.

[17] M. Y. Afoan and A. D. Corebima, "The Correlation of Metacognitive Skills and Learning Results Toward Students' Retention of Biology Learning: Students Learning Only to Pass Examinations," Educational Process: International Journal, vol. 7, no. 3, pp. 171-179, 2018, doi: 10.22521/edupij.2018.73.1.

[18] A. E. Kesici, D. Guvercin, and H. Kucukakca, "Metacognition researches in Turkey, Japan, and Singapore," International Journal of Evaluation and Research in Education (IJERE), vol. 10, no. 2, pp. 535-544, 2021, doi: 10.11591/ijere.v10i2.20790.

[19] T. M. Miller, "Measurement, Theory, and Current Issues in Metacognition: An Overview," in Metacognition in Chemistry Education: Connecting Research and Practice. American: American Chemical Society, 2017, pp. 1-15.

[20] S. Hadiati, H. Kuswanto, D. Rosana, and A. Pramuda, "The effect of laboratory work style and reasoning with Arduino to improve scientific attitude," International Journal of Instruction, vol. 12, no. 2, pp. 321-336, 2019, doi: 10.29333/iji.2019.12221a.

[21] P. Ranjendran and R. Anandarasu, "Study on Scientific Attitude of B. Ed Trainees in Parambalur District," International Journal of Education, vol. 8, no. 4, pp. 105-110, 2020, doi: 10.34293/education.v8i4.325.

[22] A. I. Pitafi and M. Farooq, "Measurement of Scientific Attitude of Secondary School Students in Pakistan," Academic Research International, vol. 2, no. 2, pp. 379-392, 2012.

[23] Zulirfan, H. Z. Iksan, K. Osman, and MNS. Salehudin, "Take-Home-Experiment: Enhancing Students' Scientific Attitude," Journal of Baltic Science Education, vol. 17, no. 5, pp. 828-837, 2018, doi: 10.33225/jbse/18.17.828.

[24] W. Sumarni, E. Susilaningsih, and Y. Sutopo, "Construct validity and reliability of attitudes towards chemistry of science teacher candidates," International Journal of Evaluation and Research in Education (IJERE), vol. 7, no. 1, pp. 39-47, 2018, doi: 10.11591/ijere.v7.i1.11138.

[25] E. Darmawan, Y. Brasilita, S. Zubaidah, and M. Saptasari, "Enhancing metacognitive skills of students with different gender using simas eric learning model at State Senior High School 6 Malang," (in Indonesia), Jurnal Pendidikan Biologi (BIOSFERJPB), Universitas Negeri Malang, vol. 11, no. 1, pp. 47-56, 2018, doi: 10.21009/biosferjpb.11-1.5.

[26] S. M. S. Cañizares and F. J. F. García, "Gender differences in Entrepreneurial Attitudes," Equality, Diversity and Inclusion, vol. 29, no. 8, pp. 766-786, 2010, doi: 10.1108/02610151011089519.

[27] S. Mahanal, "Biology learning strategy, gender, and its effect on critical thinking skills," (in Indonesia), Proceeding Biology Education Conference, vol. 9 no. 1, 2012, pp. 179-184. [Online]. Available: https://jurnal.uns.ac.id/prosbi/article/view/7442.

[28] A. Vello, M. Rani, and K. Hariharan, "The Role of Gender in the Use of Metacognitive Awareness Reading Strategies among Biology Students," Asian Social Science, vol. 11, no. 1, pp. 67-73, 2015, doi: 10.5539/ass.v11n1p67.

[29] A. Bernik, D. Vusić, and M. Milković, "Evaluation of Gender Differences Based on Knowledge Adaptation in the Field of Gamification and Computer Science," International Journal of Emerging Technologies in Learning (iJET), vol. 14, no. 8, pp. 220-228, 2019, doi: 10.3991/ijet.v14i08.9847.

[30] J. Osborne, S. Simon, and S. Collins, "Attitudes Towards Science: A Review of the Literature and Its Implications," International Journal of Science Education, vol. 25, no. 9, pp. 1049-1079, 2003, doi: 10.1080/0950069032000032199.

[31] K. D. Gurel, "Development of An Optics Interest and Experience Scale (OIES) and Exploring Gender Differences in Prospective Teachers' Interest and Experience," Journal of Baltic Science Education, vol. 17, no. 6, pp. 935-952, 2018 .

[32] W. Saputri and A. D. Corebima, "The Correlation between Metacognitive Skills and Cognitive Learning Results of Biology Pre-service Teachers on Different Learnings," Journal of Turkish Science Education, vol. 17, no. 4, pp. 487-503, 2020.

[33] M. Palennari, "Exploring The Correlation Between Metacognition and Cognitive Retention of Students Using Some Biology Teaching Strategies," Journal of Baltic Science Education, vol. 15, no. 5, pp. 617-629, 2016, doi: $10.33225 / \mathrm{jbse} / 16.15 .617$.

[34] A. Bahri and A. D. Corebima, "The Contribution of Learning Motivation and Metacognitive Skill on Cognitive Learning Outcome of Students with in Different Learning Strategies," Journal of Baltic Science Education, vol. 14, no. 4, pp. 488-490, 2015.

[35] A. M. Amin and R. Adiansyah, "Identification of preservice biology teachers' metacognitive awareness and metacognitive skill," J. Phys.: Conf. Ser., vol. 1511, 2020, doi: 10.1088/1742-6596/1511/1/012029.

[36] D. Rumahlatu, and K. Sangur, "The influence of project-based learning strategies on the metacognitive skills, concept understanding and retention of senior high school students," Journal of Education and Learning (EduLearn), vol. 13, no. 1, pp. 104-110, 2019, doi: 10.11591/edulearn.v13i1.11189.

[37] A. Muhlisin, H. Susilo, M. Amin, and F. Rochman, "Analysis of Metacognitive Skills viewed from Differences of academic Ability in Science Basic Concept Lecture," (in Indonesia), Proceeding, Seminar Nasional Biologi, Surabaya: Universitas Negeri Surabaya, 2016.

[38] S. Amnah, "The Profile of the Awareness and Metacognitive Strategies of new Students of Biology Education in Teacher Training and Education Faculty, Universitas Islam Riau Pekanbaru," (in Indonesia), Jurnal Pendidikan IPA Indonesia, vol. 3, no. 1, pp. 22-27, 2014. [Online]. Available: https://journal.unnes.ac.id/nju/index.php/jpii/article/view/2897. 
[39] D. Tomasi and N. D. Volkow, "Gender differences in brain functional connectivity density," Human Brain Mapping, vol. 33, no. 4, pp. 849-860, 2012, doi: 10.1002/hbm.21252.

[40] Z. F. Zaidi, "Gender differences in human brain: A Review," The Open Anatomy Journal, vol. 2, pp. 37-55, 2010, doi: $10.2174 / 1877609401002010037$.

[41] Y. Sya'bandari, M. Ha, K.J. Lee, and S. Shin, "The Relation of Gender and Track on High School Students' Attitude Toward Convergence," Journal of Baltic Science Education, vol. 18, no. 3, pp. 417-434, 2019, doi: $10.33225 / \mathrm{jbse} / 19.18 .417$.

[42] A. Rachmatullah, S. Diana, and M. Ha, "Identifying Indonesian Upper-Secondary School Students' Orientations to Learn Science and Gender Effect Through The Use of Structural Equation Modeling," Journal of Baltic Science Education, vol. 17, no. 4, pp. 633-648, 2018, doi: 10.33225/jbse/18.17.633.

[43] Kamid, M. Rusdi, O. Fitaloka, F. R. Basuki, and K. Anwar, "Mathematical communication skills based on cognitive styles and gender," International Journal of Evaluation and Research in Education (IJERE), vol. 9, no. 4, pp. 847-856, 2020, doi: 10.11591/ijere.v9i4.20497.

[44] M. Demirel, I. Askin, and E. Yagc1, "An Investigation of Teacher Candidates' Metacognitive Skills," ProcediaSocial and Behavioral Sciences, vol. 174, pp. 1521-1528, 2015, doi: 10.1016/j.sbspro.2015.01.783.

[45] D.F.M. Garzon, A.P.H. Bistos, and J.O.U. Lizarazo, "Relationship between Metacognitive Skills, Gender, and Level of Schooling in High School Students," Suma Psicologica, vol. 27, no. 1, pp. 9-17, 2020, doi: 10.14349/sumapsi.2020.v27.n1.2.

[46] P. T. Oon, M. M. W. Cheng, Cheng, and A. S. L. Wong, "Gender Differences in Attitude Towards Science: Methodology for Prioritising Contributing Factors," International Journal of Science Education, vol. 42, no. 1, pp. 89-112, 2020

[47] S. N. Kumari and K. Saraladevi, "Gender Differences in Attitude towards Science Teaching and Learning Style among Adolescents," International Journal of Science and Research, vol. 3, no. 10, pp. 50-58, 2014.

[48] N. Ismirawati, A. D. Corebima, S. Zubaidah, R. H. Ristanto, and A. Nuddin, "Implementing ERCoRe in learning: Will metacognitive skills correlate to cognitive learning result?" Universal Journal of Educational Research, vol. 8, no. 4, pp. 51-58, 2020, doi: 10.13189/ujer.2020.081808.

[49] A. M. Amin, A. D. Corebima, S. Zubaidah, and S. Mahanal, "The Correlation between Metacognitive Skills and Critical Thinking Skills at the Implementation of Four Different Learning Strategies in Animal Physiology Lectures," European Journal of Educational Research, vol. 9, no. 1, pp. 143-163, 2020.

[50] N. N. Hassan, K. Sansudin, and S. C. Said, "The relation of metacognitive awereness multiple intellegences, and gender with undergraduates' perceived motivation in using multimedia," The International Journal of Multimedia \& Its Applications (IJMA), vol. 9, no. 4, pp. 25-38,2017, doi: 10.5121/ijma.2017.9603.

[51] M. J. Legato, Why Men Never Remember and Women Never Forget. New York: Rodale, 2005.

[52] S. Sumarni and N. Rachmawaty "Gender Difference in Language Learning Strategies," Ethical Lingua: Journal of Language Teaching and Literature, vol. 6, no. 1, 2019, doi: 10.30605/ethicallingua.v6i1.1169.

[53] E. Makarova, B. Aeschlimann, and W. Herzog, "The gender gap in STEM fields: The impact of the gender stereotype of math and science on secondary students' career aspirations," Frontiers in Education, vol. 4, 2019, doi: 10.3389/feduc.2019.00060.

[54] M. Mulyani, and D. Muhtadi, "Student error analysis in solving Higher Order Thinking Skill type of trigonometric task review from gender," (in Indonesia), JPPM (Jurnal Penelitian dan Pembelajaran Matematika), vol. 12, no. 1, pp. 1-16, 2019, doi: 10.30870/jppm.v12i1.4851.

[55] D. K. Fardah, "Process analysis and students' creative thinking skills in mathematics by open-ended assignments," (in Indonesia), Kreano, Jurnal Matematika Kreatif- Inovatif, vol. 3, no. 2, pp. 91-99, 2012. [Online]. Available: https://journal.unnes.ac.id/nju/index.php/kreano/article/view/2616.

[56] R. Kusumawati and A. Nayazik, "Mathematical Anxiety of Senior High School Students based on Gender," (in Indonesia), Journal of Medives, vol. 1, no. 2, pp. 92-99, 2017. [Online]. Available: http://ejournal.ivet.ac.id/index.php/matematika/article/view/485

[57] E. Suryawati, K. Osman, and T. S. M. Meerah, "The effectiveness of RANGKA contextual teaching and learning on student problem skills and scientific attitude," Procedia - Social and Behavioral Science, vol. 9, pp. 1717-1721, 2010, doi: 10.1016/j.sbspro.2010.12.389.

[58] T. Supriyadi, J. Julia, and E. Firdaus, "The Problem of Gender Equality: A Reconstruction of Islamic Doctrine," Journal of Social Studies Education Research, vol. 24, no. 2, pp. 91-110, 2019.

[59] L. M. Hanson, J. F. Westerlund, and P. W. Vaughan, "Gender Differences in Student Attitudes towards Science in Secondary School Classrooms with and without NSF GK-12 Resident Scientists," Electronic Journal for Research in Science \& Mathematics Education. vol. 24, no. 4, pp. 50-68, 2020.

[60] D. P. Suherman, W. Purwianingsih, and S. Diana, "The analysis of self-efficacy and metacognitive and its relation with academic performance of high school students based on gender on genetics concept," (in Indonesia), Assimilation: Indonesian Journal of Biology Education, vol. 1, no. 1, pp. 14-20, 2018, doi: 10.17509/aijbe.v1i1.11450.

[61] A. Fauzi and W. Sa'diyah, "Students' Metacognitive Skills from the Viewpoint of Answering Biological Questions: Is It Already Good?" Jurnal Pendidikan IPA Indonesia (JPII), vol. 8, no. 3, pp. 317-327, 2019. [Online]. Available: https://journal.unnes.ac.id/nju/index.php/jpii/article/view/19457.

[62] I. Kisac and Y. Budak, "Metacognitive strategies of the university students with respect to their perceived selfconfidence levels about learning," Procedia - Social and Behavioral Sciences, vol. 116, pp. 3336-3339, 2014, doi: 10.1016/j.sbspro.2014.01.759. 
[63] T. Bidjerano, "Gender differences in self-regulated learning," Paper presented Annual Meeting of the Northeastern Educational Research Association, Kerhonkson, New York, 2005.

[64] P. Mesaros, M. Mesarosova, and L. Mesarosova, "Learning to Learn Competency, Metacognitive Learning Strategies and Academic Self Concept of University Students," International Journal of Arts and Sciences, vol. 5, no. 2, pp. 489-497, 2012 .

[65] M. J. Hogan, C. P. Dwyer, O. M. Harney, C. Noone, and R. J. Conway, "Metacognitive Skill Development and Applied Systems Science: A Framework of Metacognitive Skills, Self-regulatory Functions and Real-world Applications,” In Metacognition: Fundaments, applications, and trends. Springer, 2015, pp. 75-106.

[66] K. J. Olasehinde and R. A Olatoye, "Scientific attitude, attitude to science and science achievement of secondary school student in Katsina State, Nigeria," J. Edu. Soc. Res., vol. 4, no. 1, pp. 445-452, 2014.

[67] G. Mihladiz, M. Duran, and A. Dogan, "Examining Primary School Students' Attitude Towards Science in Terms of Gender, Class Level, and Income Level," Procedia-Social and Behavioral Sciences, vol. 15, pp. 2582-2588, 2011, doi: 10.1016/j.sbspro.2011.04.150.

[68] W. S. Winkel, Learning Psychology (in Indonesia). Jakarta: Grasindo, 2004

[69] F. Sophianingtyas and B. Sugiarto, "Identifying Students' metacognitive Skill Level in solving Chemical Computation Problems," (in Indonesia), UNESA Journal of Chemical Education, vol. 2, no. 1, pp. 21-27, 2013. [Online]. Available: https://jurnalmahasiswa.unesa.ac.id/index.php/journal-of-chemicaleducation/article/view/1111.

[70] N. Kristiani, H. Susilo, and A. D. Corebima, "The correlation between attitude toward science and cognitive learning result of students in different biology learnings," Journal of Baltic Science Education, vol. 14, no. 6, pp. 723-732, 2015, doi: 10.33225/jbse/15.14.723.

[71] M. Nolan, T. Beran, and KG. Hecker, "Survey Assessment Students' Attitude Toward Statistic: A Systematic Review of Validity and Reliability," Statistics Educ. Res. J. vol. 11, no. 2, pp. 103-123, 2012.

[72] B. Rubini and Liliasari, "Basic natural sciences contribution for scientific attitude development and values of life," Int. J. Sci. Res., vol. 2, no. 5, pp. 465-468, 2013, doi: 10.1088/1742-6596/1028/1/012206.

[73] Ş. Yaşar and Ş. Ş. Anagün, "Reliability and Validity Studies of the Science and Technology Course Scientific Attitude Scale," Journal of Turkish Science Education, vol. 6, no. 2, pp. 43-54, 2009.

[74] A. Tasdemir and T. Kartal, "Survey of The Science and Primary School Teachers Candidates' Scientific Attitudes in Terns of Multi-Variables," Journal of Turkish Science Education, vol. 10, no. 1, pp. 44-55, 2013.

[75] A. M. Amin and R. Adiansyah, "Identifying students' learning styles and their responses to determine learning strategies in Animal Physiology Lecture," (in Indonesia), Jurnal Biologi \& Pembelajaran, vol. 5, no. 1, pp. 1-9, 2018. [Online]. Available: https://ojs.unpkediri.ac.id/index.php/biologi/article/view/12036.

[76] A. Usta, H. Bodur, D. Yağız, and A. M. Sünbül, "İlköğretim fen bilgisi derslerinde öğrenme stillerine dayalı öğretim etkinliklerinin öğrenci erişi ve tutumlara etkisi," Selçuk Üniversitesi Ahmet Keleşoğlu Eğitim Fakültesi Dergisi, vol. 13, pp. 1-13, 2011

[77] Q. Alam, "Impact of the school outreach tour program of citizens archive of Pakistan on students perceptions and attitudes," International Journal of Instruction, vol. 10, no. 1, pp. 289-306, 2017.

[78] A. Bahri, S. I. Idris, and H. N. Samsidi, "Biology cognitive retention and scientific attitudes of different academic ability students at the implementation of PBLRQA integrated with learning journals," (in Indonesia), Jurnal Sainsmat, vol. 8, no. 1, pp. 85-97, 2019, doi: 10.35580/sainsmat81101912019.

[79] R. Karnain, S. Rahman, and S. Surat, "Usability of M-PA21 Module to Improve Teachers' Metacognitive Regulation in Teaching and Application of 21st Century Basic Skills," International Journal of Emerging Technologies in Learning (iJET), vol. 14, no. 20, pp: 87-105, 2019.

[80] R. Adiansyah, D. Safitri, and S. Bachtiar, "The critical Thinking Skills of different academic Ability Students at the Implementation of PBL Integrated with Jigsaw Learning Model," (in Indonesia), Proceeding of Seminar Nasional Hayati 2017. Universitas Nusantara PGRI Kediri, 2017, pp. 292-299. [Online]. Available: http://conference.unpkediri.ac.id/index.php/hayati/hayati5/paper/view/61. 